\title{
Creating A Material Resource for History Students Using Local History Content Entitle "Banyumas before Diponegoro War (1755-1825)"
}

\author{
Prof. Dr. Sugeng Priyadi, M. Hum. \\ History Education Department \\ Teacher Training and Educational Faculty \\ Universitas Muhammadiyah Purwokerto
}

\begin{abstract}
This paper describe about the Development of Teaching Material Based local history for University students in Historical subject. The title of the learning resource is Banyumas before Diponegoro War (1755-1825). The method used is the Research and Development. The results show the development of teaching materials based on the local historical value entitle Banyumas before Diponegoro War (1755-1825) assist students in obtaining better understanding about local history, it also assist the student to self-assess and to become a self-directed learner and to become critically literate.
\end{abstract}

Key words: material development, local history, students learning

\section{A. Introduction}

Teaching materials include handouts, unit outlines, or textbooks, can help students to learn. They may be more considered as learning resources.

The quality and the accessibility of these resources are equally important. The quality of learning resources is determined by whether they support students in achieving the expected learning outcomes. The accessibility of the learning resources may include the timeliness and ease of access, as well as the usability for students with special needs.

In line with this, According to Painga (2017) In student-centred programmes, the most appropriate resources are 'real materials' that are linked to student goals. These materials can be used to create learning resources that will meet the specific needs of the student. The teaching strategies and accompanying learning resources that a tutor uses are significant factors in determining whether students make progress.

\section{B. Methods}

Reseach and development methods was appied to develop the material. Some integrative sources from the bok as well as direct investigation was used to make a goog learning souces

\section{Material Development Result}

\section{Impact to the Students}

Based on the investiagation, the material resource created have some excelence such as;

1. The learning resource is easy to use

2. The learning resource is gender and culturally appropriate, of interest to the student, and promote inclusive practice.
3. The learning resource have information that are pitched at the student's skill level and be presented in a sequence that will assist learning.

4. The learning resource assist the student to self-assess and to become a self-directed learner.

5. The learning resource assist the student to become critically literate

Result of Learning Resource Development

The reseult of learning resource develipment was presented in this paper as a resource for history teacher, and it comprises into some parts.

\section{Introduction}

The event related to the Java War is the Giyanti Agreement, which divided Mataram Sultanate into two, i.e. Surakarta Sunanate and Yogyakarta Sultanate. Surakarta was the centre of Mataram Sultanate, after Mataram's capital was moved from Kartasura, until the Giyanti Agreement (Soeratman, 1989: 1). This divide et impera politic made Java, especially Mataram, weaker because that division could not be separated from territory division. Banyumas, located in the west of Yogyakarta, was actually under the rule of Surakarta Sunanate. However, the $9^{\text {th }}$ Banyumas Regent, Tumenggung Yudanegara III (1749-1755), was appointed by the Prince of Mangkubumi as pepatih dalem of Yogyakarta Sultanate. Thus, an inverse position had happened. In Mangkubumen War, Tumenggung Yudanegara III, became the opponent of Prince Mangkubumi. In that position, one of Tumenggung Yudanegara III's younger brothers, Dipayuda I who served as a ngabehi (a 
noble title for a palace official) in Pamerden (the forerunner of Purbalingga), became the victim.

According to Babad Banyumas (a historical story about Banyumas), Dipayuda died during the battle in Jenar, Kebumen so that he was called posthumous Dipayuda Seda Jenar (Dipayuda who died in Jenar). Another posthumous name was Dipayuda Seda Ngrana, which meant Dipayuda who died in the battlefield. Dipayuda's death then changed the history of Banyumas in a broad meaning. The position of ngabehi in Pamerden was then replaced by Dipayuda II, one of Tumenggung Yudanegara III's sons so that the last Dipayuda was called Dipayuda II in babad (a historical story) works. Meanwhile, Dipayuda I refered to the killed Dipayuda.

\section{B. Banyumas within 1755-1825 Periods}

Another very historical thing for Banyumas descendants is the appointment of Tumenggung Yudanegara III for being pepatih dalem entitled Raden Adipati Danuredja as the first patih (the prime minister). The position of Banyumas Regent was replaced by Tumenggung Yudanegara III's son whose title was Tumenggung Yudanegara IV (1755-1780). This $10^{\text {th }}$ Banyumas Regent was in a rather difficult position since he was the regent under the rule of Surakarta Sunanate, while his father was a pepatih dalem of Yogyakarta Sultanate. In babad works, Tumenggung Yudanegara IV suffered the fate of dismissal in 1780 because he was allegedly conspired with his father. Or, he was rumoured to hide Bugis troops in Banyumas. As a result of his dismissal, he was replaced by a local official from Surakarta Sunanate known as Tumenggung Kemong. In babad works, the name Tumenggung Kemong derived from the Tumenggung habit of calling his subordinates by sounding bende (a little gong). Tumenggung kemong, whose real name was Tumenggung Toyakusuma, served as Banyumas Regent for 8 years (1780-1788).

Tumenggung Toyakusuma also suffered the same fate with his predecessor. He was dismissed and replaced by Tumenggung Yudanegara IV's son whose title was Tumenggung Yudanegara V (1788-1813). This $12^{\text {th }}$ Banyumas Regent served for 28 years, entering British colonial period in Indonesia. Most of babad works connected this Banyumas Regent with the presence of Stanmford Raffles, especially with the dismissal of Tumenggung Yudanegara V.

Governor General Raffles became a local story that he did visits through Banyumas. Another story was that there was rumour stating that Yudanegara $\mathrm{V}$ asked Raffles to appoint him to be a Sultan in Banyumas. Moreover, Raffles then complained
Yudanegara V's request to Susuhunan Pakubuwana IV (1788-1820) in Surakarta (Priyadi, 2009: 100). As the consequence, Yudanegara V was dismissed from his position. However, this rumour seemed to be doubtful since Raffles never seemed to come to Banyumas (compared with Hannigan, 2016). Therefore, babad works then made a new story that Yudanegara $\mathrm{V}$ was dismissed since he revolted (mbalela) and wanted to be an independent king in Banyumas by planting kurung bayan tree or twin bayan in Banyumas square. The second version seemed to be stronger than the first one, but babad works stated that the decision of dismissing Yudanegara V came from Raffles's provocation to Susuhunan Pakubuwana IV. This happened because Raffles was actually afraid of that Banyumas Regent. As a result of this dismissal, Tumenggung Yudanegara $\mathrm{V}$ was called Yudanegara Pamungkas, which meant the last Yudanegara because after the 1816 inccident, Yudanegara name was no longer used by the next successors. Yudanegara V was also called Yudanegara Lengser since his position was revoked by the king.

The dismissal of Yudanegara $\mathrm{V}$ was recorded in Tedhakan Serat Soedjarah Joedanagaran (one of Danurejan B's version) (Priyadi, 2007: 101; 2010: 50). The text stated that in Mulud or Rabiul Awal (two months in Java calendar) of Ehe Year of 1740, Yudanegara V was dismissed which was continued by the division of Banyumas. If Mulud Ehe 1740 was converted to $\mathrm{AD}$ (Masehi Year), it can be known that it coincided with November 1812. Thus, the dismissal was predicted to occur in 1812 or in the beginning of 1813 (Soedarmadji, 1981: 3; 1982: 43; 1991: 46). The Babad works emphasized that there was a three years vacuum between the dismissal with the division of Banyumas (palihan Banyumas). Banyumas division took place in Mulud, Dal Year of 1743 (a sengkalan, i.e. Javanese way to remember year, sounding mantri papat resi nabi) according to Babad Pasir text or Javanese Year of 1743 according to the text of Tedhakan Serat Babad Banyumas (Knebel, 1900 \& 1901). Dal Year of 1743 was converted into February 1816. In Banyumas history, there are five regents using Yudanegara title. Yudanegara IV and $\mathrm{V}$ were dismissed by the king. Yudanegara I was executed by the king so that he was called Tumenggung Kokum. He was executed in a mosque in Todan Surakarta so that he was also notorious as Tumenggung Seda Masjid or Tumenggung Todan. Yudanegara II was also executed, but before the execution, he had died of fear in the regency hall. Therefore, his posthumous name was Tumenggung Seda Pendapa. Another version, Yudanegara II died of suicide. He drank 
overdose sleeping pills in the hall because he had already known that he would get the King's punishment. Yudanegara III was the only Banyumas Regent using Yudanegara title who did not have bad luck, either by getting dismissal or even death penalty. Yudanegara III even had a very good luck because he was chosen and appointed to be pepatih dalem of Yogyakarta Sultanate.

The dismissal of Yudanegara $\mathrm{V}$ had an effect on Banyumas division into two wedana districts, i.e. Kasepuhan and Kanoman. The division was similar with the Giyanti 1755 which had divided Mataram into Surakarta Sunanate and Yogyakarta Sultanate. The experience of Surakarta Sunanate dealing with the colonialists was implemented in Banyumas because there was a tendency that Banyumas was growing stronger. Furthermore, Yudanegara III's position as pepatih dalem of Yogyakarta Sultanate either directly or indirectly influenced the political behaviour of Banyumas Regent.

The two successors of Yudanegara III were more inclined to Yogyakarta so that they were dismissed. The next successors were two people with wedana bupati (the regent's assistant) position, i.e. Kasepuhan and Kanoman. Kasepuhan officers came from the central kingdom, meanwhile Kanoman officers came from Banyumas descendants, i.e. Yudanegara III's other grandchildren. The Palihan of Banyumas was basically divide et impera politics imitated by Susuhunan Paku Buwana IV (1788-1820) against Mataram split by colonialist (VOC). The dismissal of Yudanegara IV did not make the successors deterrent. They more eagerly seemed to be independent from Surakarta Sunanate. In fact, Yudanegara $\mathrm{V}$ did not directly become the successor of his father because his father was replaced by Tumenggung Toyakusuma. After Toyakusuma did not take care of Banyumas, he was also dismissed. Yudanegara V was appointed to replace Toyakusuma. The effect of Yudanegara V's dismisal made no one of his descendant becomes Banyumas Regent. In other words, Yudanegara V's descendants were eliminated from the circle of power or they became common people.

Kasepuhan and Kanoman as wedana bupati were the coordinator of the subordinate anom regents. The two were ngabehi former officers of Pasir Kertawibawa which was also split into two after Ngabehi Natawijaya was dismissed. They were placed in Purwokerto and Sokaraja. After becoming wedana bupati Kasepuhan, Cakrawedana was replaced by Raden Ngabehi Cakradireja in Purwokerto. Meanwhile,
Mertadireja I was replaced by Raden Ngabehi Kertadireja in Sokaraja. Each of them was under the coordination of their father. Purwokerto and Sokaraja formerly were the division territory of Pasir Kertawibawa.

The fragmentation toward the potentially revolt area made Panjer and Banjarnegara were also divided into two. The two officers in Panjer, either Reksapraja or Suradireja, came from the central kingdom. The ancestor of Suradireja was Arung Binang I, the Regent of Sewu Numbak Anyar in Surakarta coming from Kebumen. It was allegedly that Suradireja was the son of Arung Binang II (Priyadi, 2004a: 65). Suradireja's position as the son-in-law of Raden Tumenggung Mertadireja I made his position stronger in some parts of Panjer. Mertadireja I was also the son-inlaw of Wangsanegara V and Wangsanegara Sugih, who also came from Kalijirek, Kebumen (Priyadi, 2004a: 85).

Meanwhile, the two officers in Banjarnegara came from Banyumas descendants. The first officer was Raden Ngabehi Ranudireja. $\mathrm{He}$ was the son of Raden Tumenggung Yudanegara IV or the brother-in-law of Cakrawedana I. The second officer was Mangunyuda III, a non-problematic local officer, which respectively were Banyak Widhe, Mangunyuda I (Mangunyuda Seda Loji), Mangunyuda II (Mangunyuda Mukti), and Mangunyuda III (Mangunbroto). At a later time, Mangunyuda III was replaced by Mangunsubroto. The five officers were well-known as the officers in Banjar Watu Lembu (Banjar Selo Lembu).

The same non-problematic thing was also occurred in Purbalingga under the rule of Kanoman so that Dipakusuma I's position is maintained in Purbalingga because he was the son of Dipayuda III, Ngabehi of Purbalingga. The problem was that the descendants of Pamerden Ngabehi (Dipayuda I) i.e. Dipayuda IV felt a phsycological connection with Purbalingga because Pamerden was the forerunner of Purbalingga. Dipayuda IV was placed in Adireja, under the rule of Kasepuhan, with the same position with Dipakusuma I. Kasepuhan had one more subordinate, i.e. Raden Ngabehi Kertapraja in Adipala. Kertapraja was the son of Donan Ngabehi, Kertarana. He was dismissed for not sending tribute to Surakarta Sunanate. For strengthening Cakrawedana I's position, Kertapraja's position was occupied by his son, i.e. Raden Cakrayuda. However, Adipala was erased and grouped with Adireja so that from the five subordinate anom regents, it became four Kasepuhan subordinate anom regents. Adireja and Adipala traditionally were under the rule of 
Banyumas District which then became Cilacap merged with Majenang.

Table 1 Kesepuhan and Kanoman Mayor

\begin{tabular}{|c|c|c|c|}
\hline \multirow{2}{*}{\multicolumn{2}{|c|}{$\begin{array}{c}\text { KASEPUHAN } \\
\text { MAYOR } \\
\begin{array}{c}\text { Raden Tumenggung } \\
\text { Cakrawedana I }\end{array}\end{array}$}} & \multicolumn{2}{|r|}{$\begin{array}{l}\text { KANOMAN } \\
\text { MAYOR }\end{array}$} \\
\hline & & \multicolumn{2}{|c|}{$\begin{array}{c}\text { Raden Tumenggung } \\
\text { Mertadireja I }\end{array}$} \\
\hline \multirow[t]{2}{*}{1.} & Adireja & \multirow[t]{2}{*}{1.} & Purbalingga \\
\hline & $\begin{array}{l}\text { Tumenggung } \\
\text { Kliwon Dipayuda } \\
\text { IV }\end{array}$ & & $\begin{array}{l}\text { Tumenggung } \\
\text { Kliwon } \\
\text { Dipakusuma I }\end{array}$ \\
\hline \multirow[t]{7}{*}{2.} & Adipala & & \\
\hline & Raden Ngabehi & & \\
\hline & Replaced by Raden & & \\
\hline & Cakrayuda (the son & & \\
\hline & $\begin{array}{l}\text { of Raden } \\
\text { Tumenggung }\end{array}$ & & \\
\hline & Cakrawedana I). & & \\
\hline & $\begin{array}{l}\text { Adipala was erased } \\
\text { and merged with } \\
\text { Adireja }\end{array}$ & & \\
\hline \multirow[t]{2}{*}{3.} & Purwokerto & \multirow[t]{2}{*}{2.} & Sokaraja \\
\hline & $\begin{array}{l}\text { Raden Ngabehi } \\
\text { Cakradireja (the son } \\
\text { of Raden } \\
\text { Tumenggung } \\
\text { Cakrawedana I) }\end{array}$ & & $\begin{array}{l}\text { Raden Ngabehi } \\
\text { Kertadireja } \\
\text { (Sumadireja, the } \\
\text { son of Raden } \\
\text { Tumenggung } \\
\text { Mertadireja I) }\end{array}$ \\
\hline \multirow[t]{2}{*}{4.} & Panjer & \multirow[t]{2}{*}{3.} & Panjer \\
\hline & $\begin{array}{l}\text { Raden Ngabehi } \\
\text { Reksapraja (the son } \\
\text { of Kartanagara, the } \\
\text { Regent of Nayaka } \\
\text { in Surakarta) }\end{array}$ & & $\begin{array}{l}\text { Raden Ngabehi } \\
\text { Suradireja (the son } \\
\text { of Raden } \\
\text { Tumenggung } \\
\text { Arung Binang II in } \\
\text { Surakarta and the } \\
\text { son-in0law of } \\
\text { Raden } \\
\text { Tumenggung } \\
\text { Mertadireja I) }\end{array}$ \\
\hline \multirow[t]{2}{*}{5 . } & Banjarnegara & \multirow[t]{2}{*}{4.} & Banjarnegara \\
\hline & $\begin{array}{l}\text { Raden Ngabehi } \\
\text { Ranudireja (the son } \\
\text { of Raden } \\
\text { Tumenggung } \\
\text { Yudanegara IV) }\end{array}$ & & $\begin{array}{l}\text { Raden Ngabehi } \\
\text { Mangunyuda III }\end{array}$ \\
\hline \multicolumn{4}{|c|}{ Tumenggung Kliwon=bupati anom } \\
\hline & Brotodiredj & & Ngatidjo \\
\hline
\end{tabular}

Cakrawedana I was the officer who came from Surakarta Sunanate. His father was Raden Tumenggung Apanji Cakranegara, Panumping Regent official. Cakranegara was the relative of Susuhunan Paku Buwana III's empress, Ratu
Kencana II or Kangjeng Ratu Beruk. Ratu Kencana II, whose teenage name was Rara Handiyah, was the mother of Susuhunan Paku Buwana IV. Raden Tumenggung Apanji Cakranegara later became a patih in Surakarta Sunanate under the name Raden Adipati Cakranegara. This patih position would be occupied by his fourth child. Cakrawedana historical text mentioned that Cakrawedana I was the 13th descendant of Sultan Demak (1480-1518), Raden Patah, or the 14th descendant of Brawijaya $\mathrm{V}$. The lineage below illustrated the origins of wedana bupati Kasepuhan of Banyumas (18161830). Cakrawedana I was the seventh child of eight children. His brother named Raden Adipati Cakranegara became patih in Surakarta Sunanate (1810-1812). From the lineage of Cakrawedana, wedana bupati Kasepuhan's official belonged to the King's close relatives. Cakrawedana I was the cousin of Paku Buwana IV.

Table 2 The Lineage Of Mertadireja I

\begin{tabular}{|c|c|c|}
\hline \multicolumn{3}{|c|}{ THE LINEAGE OF MERTADIREJA I } \\
\hline 1. & $\begin{array}{l}\text { Raden Tumenggung } \\
\text { Yudanegara III }\end{array}$ & \\
\hline 2. & Mertawijaya & Kedungrandu \\
\hline 3. & $\begin{array}{l}\text { Raden Ngabehi } \\
\text { Atmasupana }\end{array}$ & $\begin{array}{l}=\text { Raden Ngabehi } \\
\text { Martasupana, mantri } \\
\text { anom }\end{array}$ \\
\hline & $\begin{array}{l}\text { Raden Rangga } \\
\text { Bratadimeja }\end{array}$ & bupati anom in Kace \\
\hline & $\begin{array}{l}\text { Raden Tumenggung } \\
\text { Mertadireja I }\end{array}$ & $\begin{array}{l}\text { Wedana Bupati } \\
\text { Kanoman }\end{array}$ \\
\hline Sou & ce: $\begin{array}{l}\text { Brotodiredjo } \\
\text { Darmosuwondo } \\
\text { Oemarmadi }\end{array}$ & \begin{tabular}{cr}
\multicolumn{1}{c}{ \& } & Ngatidjo \\
1969: & $48-49 ;$ \\
$\&$ & Koesnadi
\end{tabular} \\
\hline
\end{tabular}

The officer of wedana bupati Kanoman was Mertadireja I. Mertadireja I was the grandson of Tumenggung Yudanegara III, pepatih dalem of Yogyakarta Sultanate. His father was Mertawijaya, the Ngabehi Singosari officer in Kedungrandu. When delivering tribute to Surakarta Sunanate, Ngabehi Mertawijaya boarded a boat in Bengawan Solo. Mertawijaya was unfortunate because his boat was overturned. This incident caused his death. His body was buried in Dawuhan cemetery. Babad works mentioned that the eldest son of Mertawijaya became santri (someone who studies religious science, usually in an Islamic boardinghouse) in Krakal, Kebumen. He was taken to be the son-in-law by Wangsanegara $\mathrm{V}$ or Wangsanegara Sugih from Kalijirek. As an intern in Surakarta Kraton, he was appointed to be a mantri anom (a nobleman in Keraton) entitled Raden Ngabehi Atmasupana or Ngabehi Martasupana. Then, Atmasupana was appointed as 
bupati anom in Kace (Sokaraja) entitled Raden Rangga Bratadimeja and also as the half of ngabehi Pasir officer namely Raden Rangga Mertadireja I, adjacent to Cakrawedana I. After Yudanegara V was dismissed, Mertadireja I was appointed as wedana bupati Kanoman because he was the younger cousin of Cakrawedana I's first wive, i.e. Mas Ajeng Banyumas (the daughter of Mas Ayu Pacinangan and Yudanegara IV) (Priyadi, 2008: 113-114). The existence of Banyumas within the existence of Kasepuhan and Kanoman had triggered the Java War.

\section{Conclusion}

The result of the material development have some impact to the student such as:

1. The learning resource have information that are pitched at the student's skill level and be presented in a sequence that will assist learning.

2. The learning resource assist the student to self-assess and to become a self-directed learner.

3. The learning resource assist the student to become critically literate

\section{REFERENCES}

Brotodiredjo, R. M. S. dan Ngatidjo Darmosuwondo. 1969. Inti Silsilah dan Sedjarah Banjumas. Bogor: tanpa penerbit.

Hannigan, Tim. 2016. Raffles dan Invasi Inggris di Jawa. Jakarta: Kepustakaan Populer Gramedia (KPG).

Knebel, J. 1900. "Babad Pasir, Volgens een Banjoemaasch Handschrift met vertaling," Verhandelingen van het Koninklijk Bataviaasch Genootshap van Kunsten en Wetenschappen, deel LI: 1-155.

Knebel, J. 1901. "Babad Banjoemas, Volgens een Banjoemaasch Handshrift beschreven," Tijdschrift van het Bataviaasch Genootschap van Kunsten en Wetenschappen, deel XLIII: 397-443.

Oemarmadi \& Koesnadi Poerbosewojo. 1964. Babad Banjumas. Djakarta: Amin Sujitno Djojosudarmo.

Priyadi, Sugeng. 2004a. Sejarah dan Kebudayaan Kebumen. Yogyakarta: Jendela.

Priyadi, Sugeng. 2004b. "Pemekaran Banyumas dalam Perspektif Sejarah," Jurnal Penelitian Humaniora, Volume 5, No. 2, Agustus. Surakarta: Lembaga Penelitian, Universitas Muhammadiyah Surakarta.

Priyadi, Sugeng. 2007. Sejarah Intelektual Banyumas. Yogyakarta: Aksara Indonesia.
Priyadi, Sugeng. 2008. "Sejarah Kota Purwokerto," Jurnal Penelitian Humaniora, Volume 9, No. 1, Februari. Surakarta: Lembaga Penelitian, Universitas Muhammadiyah Surakarta.

Priyadi, Sugeng. 2009. Sejarah Mentalitas Brebes. Yogyakarta: Ombak.

Priyadi, Sugeng. 2010. "Dinamika Sosial Budaya Banyumas dalam Babad Banyumas Versi Wirjaatmadjan: Suntingan Teks dan Terjemahan." Disertasi. Yogyakarta: Fakultas Ilmu Budaya, Universitas Gadjah Mada.

Priyadi, Sugeng. 2015. Menuju Keemasan Banyumas. Yogyakarta: Pustaka Pelajar.

Soedarmadji. 1981. "Kabupaten Banyumas," Buku Peringatan Sadranan, edisi 11 Ruwah 1913 atau 14 Juni 1981. Purwokerto: Yayasan Pesarean Dawuhan.

Soedarmadji. 1982. "Raden Adipati Cakrawedana I Bupati Banyumas XIII, 1816-1830," Buku Peringatan Sadranan, edisi 14 Ruwah 1914 atau 6 Juni 1982. Purwokerto: Yayasan Pesarean Dawuhan.

Soedarmadji. 1991. "Kangjeng Kalibogor," Buku Peringatan Sadranan, edisi 23 Ruwah 1923 atau 10 Maret 1991. Purwokerto: Yayasan Pesarean Dawuhan.

Soeratman, Darsiti. 1989. Kehidupan Dunia Kraton Surakarta 1830-1939. Yogyakarta: Taman Siswa.

Te Poutama Painga. 2017.Creating Learning Resources In-House - Checklist Qua lity Assurance Standards of Literacy Aotearoa. Rerieved from: http://www.literacy.org.nz/sites/default/files/doc uments/Tutorresources/CreatingLearningResources.pdf 